\title{
Indian Export Incentives
}

Reprinted with permission from Journal of Development Economics, vol. 6 (1979), pp. 103-17 



\title{
INDIAN EXPORT INCENTIVES
}

\author{
Deepak LAL* \\ Unversity College, London, England
}

Received October 1976, final version received July 1978

This paper analyses Indian export incentives withn the framework of piecemeal 'second-best' welfare economics, takıng the extant import control system as a binding constrant It provides a condensed account of recent Indian export incentives together with some quantitative estimates (based on firm level data for some engineerng good exporters) of their likely effects on feasible second-best welfare levels.

\section{Introduction}

With the limitations of import substituting industrialisation becoming apparent in both theory and practice, many developing countries are currently trying to move towards policies which emphasise export promotion as much as import substitution. Many are reluctant, however, to follow the optimal trade policies recommended by economists for varying reasons. In particular they are unwilling to completely abandon their past systems of import control. India is a prime example of such a developing country. Given these self-imposed constraints, trade policy issues are confined to the area of the $n$th best, with no (or little) change being allowable on the import control side, but with export promotion being introduced as an important additional policy objective. Though trade theorists [Bhagwati (1968), Corden (1974) amongst others] have emphasised the hierarchic ranking of alternative trade policy options given various constraints on 'higher level' policies, the ensuing principles have not (to the best of my knowledge) been applied to assess the $n$th best trade policy options facing a particular country. As in many developing countries much of the current policy debates are likely to be about alternative $n$th best policies, it is important to assess them within an $n$th best general equilibrium framework. In this paper we analyse the specific case of Indian export incentives within the general equilibrium

* This paper was written whilst I was working as a consultant to the World Bank. Any errors of omission or commission, as well as the views expressed, are the author's responstbility and should not be ascribed in any way to the World Bank. Comments from members of the SSRC International Economics Workshop where the paper was presented, as well as those from an anonymous referee are gratefully acknowledged. 
framework of piecemeal welfare economies provided by Lloyd (1974), Hatta (1977) and Dixit (1975). The paper also provides an illustration of the way in which the shadow pricing rules due to Little-Mirrlees (1974) can be used to evaluate policies other than those concerned with investment appraisal.

Section 2 of the paper provides a summary account of the Indian export incentive system (as of 1975-76). The third section attempts to assess whether these implicit/explicit subsidies were $n$th best welfare improving.

\section{Export incentives (1975-76)}

Since the early 1960s the Indian government has recognised that the protective import control system it has operated to foster import substituting industrialisation has had a significant home-market bias. To offset the resultant discrimination against exports various methods of direct and indirect subsidisation of exports were adopted. Descriptions and analyses of the incentive system till 1970 are provided by Lal (1969), Bhagwati and Desai (1970) and Bhagwati and Srinivasan (1976). For our purposes a brief outline of the five forms of export incentives current in India in 1975-76 is required. Their essential features can be summarised as follows:

(a) Cash assistance: This is a direct ad valorem subsidy expressed as a given percentage of the fob value of exports, with specific rates for different goods. In 1975-76, cash assistance rates were specified individually for over five hundred commodities ${ }^{1}$ and ranged from 4 to 25 percent of fob value. There was a wide dispersion of rates even within the same general industrial category. Also these multiple rates were altered from one licensing period to the next. For certain goods the basis for fixing the cash assistance rates was not the fob value but a percentage of the freight costs subject to a ceiling in terms of fob value. For some other goods the cash assistance varied with the import content of exports, whilst for at least one good [transmission line towers galvanised (high tensile steel)] we were able to identify that the cash assistance rate is decided on a 'case-by-case basis'.

Finally, therev were restrictions in terms of the direction of exports for eligibility for cash assistance in the case of some products. Whilst cash assistance 'was available to producers who supplied indigenous inputs to IDA, IBRD, UNDP and ADB projects in India, if the payment was made in free foreign exchange.

(b) Import duty and indirect tax drawbacks: The scheme, which was meant to cover all 'exports', enabled exporters to obtain refunds of customs and

\footnotetext{
${ }^{1}$ A useful compilation of the coverage of the cash assistance schemes, as well as the rates of assistance for different commodittes is in Pocket Book of Export Cash Assistance (The Export Times) 1975-76 edition with various supplements.
} 
central excise dutics pard on raw materials and components used in export production.

The drawbacks were not based on actual duties paid, but on various norms relating to the average estimate of the incidence of these duties on export products by the Ministry of Commerce. These rates were fixed for specific products.

But lacking the necessary detalled cost and tax information at the firm or industry level, these drawback rates were fixed in a relatively 'ad hoc' manner.

(c) Import replenishment (REP) licences: These licences enabled exporters to import certain raw materials, components and machinery used in the manufacture of the export product or needed for its further development.

The REP licences were issued on the basis of a fixed proportion of the fob value of exports and differed from those in the pre-devaluation import entitlement schemes primarily in the rate of import replenishment provided. Whereas under the old entitlement schemes exporters were issued import licences for twice the direct import content of their exports, under the REP scheme only the single import content is replaced. These fob REP rates ranged from $5 \%$ to as high as $70 \%$ of fob value.

The REP licences are issued after the exports have been effected. More recently two additional schemes, building on the REP scheme, have been added to supplement the availability of imports for exporters. The first is through the imprest scheme, under which REP licences equal to the amount of direct imports in the exports of the past year are granted at the beginning of the current licensing year. Secondly, supplementary REP licences have also been introduced, and are granted on an essentially 'ad hoc' basis where the original provision is considered to be 'inadequate' to accommodate an essential raw material or component which is required to be imported on the grounds that the quality of the indigenous substitute is not adequate or its price is too high to maintain the competitiveness of the export product, or if there is insufficient supply of the indigenous substitute. There are further concessions both in the quantum of licences granted, as well as in allowing imports from preferred currency sources, for firms who export over $20 \%$ of their output as well as for those whose domestic value added is over $50 \%$ of their export price.

These REP licences are generally issued in the name of manufacturers. But the exporter can nominate other firms in the same or closely allied industries for his REP licences, and to this extent they are transferable and earn a varıble premium. As the licences generally specify both the items which can be imported as well as the source of imports (in terms of specific currencies) the premia will vary depending upon the demand and supply for particular 
import commoditıes from different sources. Thus the premia will be diversified both for commodities and even within the same commodity category for different import sources.

Till recently, moreover, as with most import licensing, REP imports were subject to the 'indigenous availability' criterion, but now the DGTD' ${ }^{2}$ has been authorised to waive this clearance for REP licences.

(d) Supply of other inputs: There are provisions for the supply of various domestically produced inputs at international prices, of which the most important is steel. The supply of a number of other raw materials is canalised through the Statc Trading Corporation; the price to exporters for items they still have to buy from the STC are however now in principle, meant to be related to world prices, and moreover, if the STC cannot supply these items within six months, the exporters can obtain a letter of authority for direct imports.

(e) Miscellaneous measures: For a number of products, railway and shipping freight rates are subsidised. There are also various schemes for providing export credit at concessional rates for exporters. Finally there are a number of industries for which compulsory export obligations have been instituted.

More recently, restrictions on the expansion of capacity have been eased for exporting industries.

\section{The welfare effects of the incentive system}

From the above review of the current incentive system it is evident that India has once again (since the partial simplification following the 1966 devaluation) erected a complex and highly differentiated set of export incentives.

What can we deduce about the effects of this system on social welfare? We try to answer this question in this part by first looking at the likely welfare effects of the individual measures, and then attempting an assessment of the likely net welfare effects of the incentive system as a whole.

\subsection{Cash subsidies}

First there is a direct export subsidy element provided by the cash assistance scheme and the premia on REP licences. These result in an effectively diversified and variable export subsidy over time. In principle [see Lloyd (1974), Dixit (1975) and Corden (1974)] the second or third-best

\footnotetext{
${ }^{2}$ The Director General of Technical Development, whose office is responsible for clearing import licences from the viewpoint of 'indigenous availability'.
} 
'optımum' export subsidy will be diversified, though not necessarily variable (unless domestic demand and supply and cost schedules and/or foretgn prices alter). However, these 'optimal' differentiated subsidy rates depend crucially upon the relevant demand and supply elasticities (including cross elasticities) for the relevant export goods.

What principles, if any, have governed the fixing of the differential cash assistance rates on different commodities? After the 1966 devaluation it was claimed that cash subsidies were meant 10 offset various unidentified domestic taxes on the inputs of the exporters. However, now it is claimed that cash assistance is designed to offset the difference between the fob realisation and the marginal (short-run, variable) cost of production. To test whether this was the basis for setting the cash assistance rates we used the firm level input, output and subsidy realisation data generated by a World Bank sponsored study of engineering export firms conducted by ICICI (Industrial Credit and Investment Corporation of India). We were only able to obtain the data on 10 firms. Table 1 shows the cash assistance rate (as a percentage of fob value of exports) which would have offset the difference between fob realisation and marginal cost for these firms, and the actual percentage rate of cash assistance provided. It also shows the total subsidy rate to exports by these firms.

From this table it is apparent that there seems to be no basis for the claim that the cash assistance or indeed total subsidy rates have been based on the principle of equating fob values with marginal costs of production. This is not surprising for the Ministry of Commerce which sets these rates does not have the basic firm level cost of production data which is required to apply this principle. In fact the ICICI survey, when it is completed, will be the first source to provide this information for a large range of engineering good export industries for the first time!

Moreover, even in principle, attempting to offset the difference between the short-run marginal private costs of production and export realisations (in an economy where private and social costs diverge) does not make economic sense. The application of this principle could lead to elther goods whose social costs were greater than their 'border' prices being exported, or else to goods being exported beyond the level where their social costs were equal to the border price. The correct principle (if we disregard comsumption costs), on which the differentiated export subsidy rate should be set is to induce that level of output from the export industry at which the marginal social cost of production is equal to the 'border' price [see Lal (forthcoming)]. But to do this it is necessary to have knowledge of the social cost curve as well as the private cost curve. The authorities lacked knowledge of the latter and certainly made no attempt to estimate the former. As a result any attempt at fine-tuning the export subsidy system with the objective of maximising the production gains were doomed at the outset. 
Table 1

Subsidy rates for $10 \mathrm{IClCl}$ exportıng firms. ${ }^{\mathrm{a}}$

\begin{tabular}{|c|c|c|c|c|c|c|c|c|}
\hline \multirow[t]{2}{*}{ Firm in industry } & \multicolumn{2}{|c|}{$\begin{array}{l}\text { Actual cash } \\
\text { subsidy (\% fob) }\end{array}$} & \multicolumn{2}{|c|}{$\begin{array}{l}\text { Hypothetical } \\
\text { subsidy to equate } \\
\text { fob and marginal cost } \\
\text { (\% fob) }\end{array}$} & \multicolumn{2}{|c|}{$\begin{array}{l}\text { Actual } \\
\text { total subsidy, } \\
\text { direct }+ \text { indirect } \\
(\% \text { fob })^{b}\end{array}$} & \multicolumn{2}{|c|}{$\begin{array}{l}\text { Divergence } \\
\text { domestic } \\
\text { and fob } \\
\text { price }(\%)^{\mathrm{c}}\end{array}$} \\
\hline & 1972 & 1974 & 1972 & 1974 & 1972 & 1974 & 1972 & 1974 \\
\hline 1. Light commercial vehicles & 19 & 27 & -12 & 15 & 113 & 28 & 96 & 96 \\
\hline 2. Wire ropes & 21 & 12 & 50 & -5 & 21 & 12 & 118 & 16 \\
\hline 3. Textıle machınery I & 10 & 10 & -20 & -8 & 20 & 10 & 3 & 3 \\
\hline 4. Textile machinery II & 10 & 10 & 19 & 29 & 11 & 13 & 28 & 25 \\
\hline 5 Abrasives & 4 & 11 & 115 & 73 & 4 & 11 & 159 & 107 \\
\hline 6 Electrical equipment & 8 & 17 & 4 & 13 & 8 & 17 & 10 & 10 \\
\hline 7. Castings and forgings & 8 & 1 & 27 & -17 & 10 & 4 & 61 & 2 \\
\hline 8. Steel tubes and pipes & 30 & 0 & 7 & -12 & 68 & 15 & 33 & 8 \\
\hline 9. Textiles & 4 & 23 & 38 & 2 & 4 & 23 & 51 & 10 \\
\hline 10 Chemicals & 0 & 0 & -43 & 17 & 0 & 0 & -12 & 18 \\
\hline
\end{tabular}

aDerived from ICICl Export Firms Survey data. The figures have been rounded in all cases.

bIncludes firm realisations from cash assistance, duty drawback. freight subsidy. steel concessions and premium on REP licences nominated. 'Derived as value of output at domestic prices to that at fob prices minus one multiplied by 100 
In practice, moreover, the cash assistance rates for different goods were essentially fixed in an 'adhoc' manner, and only to the extent they happened to provide some offset to the disincentives to exporting for goods in which India had a comparative advantage and for which the level of exports was less than the socially 'optimal' level, could they have led to social welfare improvements.

\subsection{REP licences}

The other element in the subsidisation of the fob value of exports was the premia firms obtained on their REP licences, for non-competitive imported inputs. Table 2 gives the varying permia rates for the $10 \mathrm{ICICI}$ firms referred to above. These REP schemes have introduced an export subsidy element of the currency retention type, and with the recent expansion of the scheme it is becoming more and more like the import entitlement schemes of the predevaluation period. ${ }^{3}$

There are various disadvantages to these schemes. First, the quantum of REP imports and hence the currency allowed to be 'retained' by the exporter is linked to import content, which, ceteris paribus, will tend to lead to the subsidies provided being higher for import intensive products, which in turn given the varying divergences between the implicit import and export exchange rates for different goods, and the faking of foreign trade returns could lead to a net loss of foreign exchange from exporting. Second, the effective subsidy differs as a result of a whole host of 'ad hoc' factors, like the products allowed to be imported or the sources of imports, or the limited and varying transferability of the licences. This differentiation can again not be given any economic justification, even though in general the 'optimal' set of export subsidies will be differentiated.

The REP licences have however, also served another and probably more useful purpose, namely in enabling exporters to overcome the rigours of the import rationing system to some extent. However, at present, with the recent import liberalisation, at least for exporters it is unlikely that this factor of import availability per se will be of much practical importance. Not surprisingly, therefore, with the introduction of the various additional REP schemes (which in effect are a move towards the earlier import entitlement currency retention type schemes), the role of the REP is looked upon more as an indirect form of export subsidisation rather than as one of easing imported raw materials availability constraints.

\subsection{Implicit exchange rates}

The net effect of the varying REP premia and the differentiated system of

${ }^{3}$ I have discussed these schemes elsewhere: sce Lal (1972). 
Table 2

Premia rates on REP licences for 10 ICICI exporting firms.

\begin{tabular}{|c|c|c|c|c|c|c|}
\hline \multirow[t]{2}{*}{ Firm in industry } & \multicolumn{2}{|c|}{$\begin{array}{l}\text { REP granted as } \\
\% \text { of fob value }\end{array}$} & \multicolumn{2}{|c|}{$\begin{array}{l}\% \text { of REP licence } \\
\text { nominated }\end{array}$} & \multicolumn{2}{|c|}{$\begin{array}{l}\text { Premia rate on } \\
\text { REP nominated } \\
\text { (\% of nominal } \\
\text { value) }\end{array}$} \\
\hline & 1972 & 1974 & 1972 & 1974 & 1972 & 1974 \\
\hline 1. Light commercial vehicles & 19 & 28 & 61 & 0 & 48 & - \\
\hline 2. Wire ropes & 3 & 3 & 0 & 12 & - & 40 \\
\hline 3 Textile machinery I & 2 & 2 & 0 & 0 & - & - \\
\hline 4. Textule machinery II & 15 & 21 & 72 & 100 & 22 & 18 \\
\hline 5 Abrasives & 0 & 0 & - & - & - & - \\
\hline 6. Electrical equipment & 0 & 0 & - & - & - & - \\
\hline 7. Castings and forgings & 52 & 4.3 & 0 & 0 & - & -. \\
\hline 8. Steel tubes and pipes & 18 & 13 & 22 & 0 & 39 & - \\
\hline 9. Textiles. & 1 & 65 & 0 & 0 & - & - \\
\hline 10. Chemicals & 0 & 0 & - & - & - & - \\
\hline
\end{tabular}

aDerived from the $\mathrm{ICICI}$ export firms survey data. 
export subsidies is to create a new system of multiple exchange rates on the export side. These are likely to have led to a further diversification of the effective exchange rates for different commodities in the economy.

In order to provide some estimates of this diversity of the effective export exchange rates, and their arbitrary variation over time, we have used the firm level data for the 10 industries from the ICICI cited earlier to estimate the implicit exchange rate for each of these firms as follows. ${ }^{4}$

Defining the implicit exchange rate for the export of a product as: that rate which if all input prices confronting producers other than those of directly imported intermediate goods in production remain constant, will leave export profitability unchanged if the subsidy system is abolished, and using the following notation:

$e^{*}=$ implicit exchange rate,

$e=$ current official exchange rate,

$V_{f_{1}}=$ foreign exchange value of the imported intermediate inputs used in producing export good $i$,

$P_{f i}=$ foreign currency price of the export good $i$,

$V_{d z}=$ value of all domestic intermediate inputs in production of $i$, including all primary factors,

$t_{i}=$ average tariff rate on the intermediate imported, inputs in good $i$,

$s_{i}=$ cash subsidy rate on exports of good $i$,

$r_{i}=$ percentage of imported input costs given as a REP licence and nominated at a premium,

$p_{r i}=$ premium rate on the REP licences of $\operatorname{good} i$,

$D_{i}=$ total value of all the duty drawbacks, for export $\operatorname{good} i$,

then, in equilibrium, with the subsidy system and the current official exchange rate:

$$
V_{d i}+e \cdot V_{f i}\left(1+t_{1}+p_{r i}\right)=e \cdot P_{f i}\left(1+s_{i}\right)+e \cdot r_{i} \cdot V_{f i} \cdot p_{r i}+D_{i} .
$$

This equation states that the domestic costs of production equal the export realisation inclusive of cash assistance, the premia on REP licences realised and the total duty drawbacks obtained.

Alternatively if the export incentive system was replaced by an exchange rate change from $e$ to $e_{1}^{*}$, but if the input-output coefficients and the prices of all domestic intermediate inputs and primary factors remained unchanged, and the tariffs on imported inputs did not alter, then

\footnotetext{
${ }^{4}$ See Ramaswamı (1972) for various derivations of this implicit exchange rate under different assumptions about trade policy.
} 


$$
V_{d t}+e_{1}^{*} V_{J_{l}}\left(1+t_{1}\right)=e_{t}^{*} P_{f l}
$$

which states that the domestic costs of production will be equal to the realisation on exports, with forelgn currency import and export values being converted at the exchange rate $e_{i}^{*}$. From (1) and (2) it follows that:

$$
e_{1}^{*}=e+\frac{e\left[P_{f_{1}} \cdot s_{1}+V_{f_{1}} \cdot p_{r_{1}}\left(r_{1}-1\right)\right]+D_{i}}{\left[P_{f_{1}}-V_{f_{1}}\left(1+t_{1}\right)\right]} .
$$

From this, the percentage divergence of the implicit exchange rate $e^{*}$, from the official exchange rate $e$, denoted by $e_{d t}$ is

$$
\begin{aligned}
e_{d_{i}} & =\left(e_{i}^{*}-e\right) / e \\
& =\left\{e\left[P_{f i} \cdot s_{1}+V_{j i} \cdot p_{r i}\left(r_{t}-1\right)\right]+D_{i}\right\} / e\left[P_{f i}-V_{f i}\left(1+t_{i}\right)\right] .
\end{aligned}
$$

This states that the implicit exchange rate will be higher than the official exchange rate for the export good $i$, by a percentage given by the ratio of the sum of the value of the cash assistance plus the total value of the premium realised on REP licences minus the implicit premium on all the intermediate imported inputs plus the total duty drawbacks, to the difference between the value of export earnings and the imported inputs, inclusive of tariffs, at the official exchange rate.

The only unfamiliar term in the above expression is likely to be the minus term in the numerator (the implicit premium on imported inputs). This appears because in the above derivation we have implicitly assumed that the full capacity requirements of the imported inputs are not provided directly to the producer through the import control system. However, it seems likely, at least for exporters (with the recent liberalisation of imports) that in the future they will be able to obtain therr imported input requirements for full capacity operation directly at the official exchange rate (plus tariffs). The import premia on nominated REP licences will then represent the implicit tax levied on other users of the same inputs, which is transferred as a direct subsidy to the exporters. The resulting value of the divergence between the implicit and official exchange rates for export good $i\left(e_{d i}^{\prime}\right)$ is then given by

$$
e_{d i}^{\prime}=\left\{e\left[P_{f i} \cdot s_{1}+V_{f i} \cdot r_{l}\right]+D_{i}\right\} / e\left[P_{f i}-V_{f i}\left(1+t_{i}\right)\right] .
$$

In table 3, columns (1) and (2), we give the estimated values of $e_{d i}$ and $e_{d i}^{\prime}$ for the ten firms for which we had data from the ICICI survey referred to above.

\subsection{Social rates of return}

No welfare significance attaches to these divergent implicit exchange rates 
Table 3

Estimates of various indices for $10 \mathrm{ICICI}$ exportıng firms."

\begin{tabular}{|c|c|c|c|c|c|c|c|c|c|c|c|c|}
\hline \multirow{2}{*}{ Firm in industry } & \multicolumn{2}{|l|}{$e_{\mathrm{dt}}^{\mathrm{b}}$} & \multicolumn{2}{|l|}{$e_{d i}^{\prime \prime}$} & \multicolumn{2}{|c|}{$r^{3}(\%)^{c}$} & \multicolumn{2}{|c|}{$r_{a}^{p}(\%)^{d}$} & \multicolumn{2}{|c|}{$r_{d}^{p}(\%)$} & \multicolumn{2}{|c|}{$r_{1 .}^{p}(\%)^{\mathrm{e}}$} \\
\hline & 1972 & 1974 & 1972 & 1974 & 1972 & 1974 & 1972 & 1974 & 1972 & 1974 & 1972 & 1974 \\
\hline 1 Light commercial vehicles & 0.48 & 0.33 & 0.53 & 033 & 28 & 20 & 6 & -9 & 49 & 41 & 44 & 13 \\
\hline 2. Wire ropes & 033 & 0.10 & 033 & 0.16 & -27 & 26 & 35 & 6 & 42 & 28 & -20 & 22 \\
\hline 3 Textile machinery 1 & 024 & 013 & 0.24 & 013 & 50 & 75 & 12 & 8 & 14 & 11 & 25 & 17 \\
\hline 4. Textıle machinery II & 012 & 0.14 & 014 & 0.14 & 17 & 24 & -8 & -19 & 4 & -3 & -4 & -11 \\
\hline 5. Abrasives & 0.04 & 0.13 & 004 & 0.13 & -55 & -38 & -42 & -31 & 16 & 15 & -30 & -26 \\
\hline 6. Electrical equipment & 0.08 & 018 & 0.08 & 0.18 & 20 & 23 & -2 & -8 & 3 & -2 & 2 & 2 \\
\hline 7. Castings and forgings & 0.12 & 0.04 & 0.12 & 0.04 & -10 & 34 & -14 & 19 & 24 & 21 & -9 & 22 \\
\hline 8. Steel tubes and pipes & 0.90 & 0.35 & 0.90 & 0.35 & -5 & 57 & -22 & 14 & 14 & 22 & -5 & 55 \\
\hline 9. Textiles & 0.05 & 0.24 & 0.05 & 0.24 & -3 & 20 & -21 & -3 & 7 & 9 & -19 & 25 \\
\hline 10. Chemicals & 0.00 & 0.00 & 000 & 0.00 & 108 & 32 & 51 & -15 & 37 & 1 & 51 & -15 \\
\hline Mean & 0.24 & 0.16 & 0.24 & 0.17 & & & & & & & & \\
\hline Standard devaation & 0.28 & 0.11 & 0.28 & 011 & & & & & & & & \\
\hline
\end{tabular}

${ }^{a}$ Derived from the ICICl export firm survey data

$e_{d_{t}}=$ percentage excess of the implicit over the offictal exchange rate assuming the full capacity imported inputs are not provided to cxporters $e_{d t}^{\prime}=$ percentage excess of the implicit over the official exchange rate assuming the full capacity imported inputs are provided to exporters. $r^{s}=$ social rate of profit,

$r_{2}^{p}=$ private rate of profit assumıng all the output is exported, and there are no incentives,

$r_{d}^{p}=$ private rate of profit assuming all the output is sold in the domestic market,

$r_{x}^{p}=$ private rate of profit assuming the output is exported and receives the same indirect and direct rate of subsidy as current exports of the firm. "Where no prema rates were available as no REP was nominated, the iwo $e_{d}$ values will be the same.

'The social rate of profit has been derived from the data for each firm with the inputs being shadow priced on Little-Mirrlees lines by using the shadow price estimates in Lal (forthcoming). The capital data was from the balance sheets of the firms. The output was priced at fob prices. The resultung rates of profit are those which would accrue assuming the actual degree of capacity utilisation if unputs and outpus were priced at 'border' prices.

"This private rate of profit has been obtaned by valuing the output at fob prices and the inputs at market prices. The capital figures were taken from the balance sheets.

'This rate of profit was obtained by valuing the output at fob prices plus total subsidies on actual exports and inputs at market prices. The capital figures were taken from the balance sheets. 
in themselves. However, it can be shown [see Lal (forthcoming)] that, with given distortions, within a general equilibrium model with importable, exportable and non-traded goods, equating the social costs of production [given by the Little-Mirrlees (LM) shadow pricing rules] to the 'border' price of exportables will be second-best welfare 'optimal', if all goods are normal in consumption, importables and non-traded goods are Hicksian substitutes in consumption, and if the transformation frontier of the net outputs of the goods is strictly convex to the origin. We can thus ask the question whether the net effect of the export subsidisation system was to lead to relatively higher implicit exchange rates for exports in which relative social profitability was greater? For if this were the case it would suggest that the net effect of the export subsidy system was second-best welfare optimal.

As the theoretical literature on cost-benefit analysis has shown, the social costs with given trade restrictions are obtained by valuing the inputs (and social benefits by valuing the output) at the shadow prices given by the socalled Little-Mirrlees rules. ${ }^{5}$ These state that for traded inputs and outputs the shadow prices are their 'border' prices, and for non-traded goods are their marginal cost of production in terms of foreign exchange. For labour the shadow wage rate is given by the sum of the output foregone elsewhere in the economy (valued at 'border' prices) plus the social costs (taking account of both intra- and intergenerational distributional considerations) of the extra consumption that any difference in the wage paid to labour in its current and previous occupations entails.

Thus, if in addition to the earlier notation we use:

$r_{s i}\left(r_{p i}\right)=$ social (private) rate of return to export industry $i$,

$P_{s}\left(P_{d j}\right)=$ the LM shadow (market) price of the non-traded good $j$,

$W_{s}(W)=$ the shadow (market) wage rate,

$a_{j i}, a_{i i}, a_{k l}=$ the physical input of the non-traded good $j$, of labour and capital, respectively, in the production of a unit of exportable output $i$,

then the social rate of return is given by

$$
r_{s t}=\left[e\left(P_{f i}-V_{f i}\right)-\sum_{j} a_{j i} \cdot P_{s j}-a_{l i} \cdot W_{s}\right] / a_{k i}
$$

From a comparison of (4), (5) and (6), it is obvious that a ranking of export industries by implicit exchange rates will not necessarily be the same as that by social rates of return. However, as the private rate of return will be given 
from (1) by

$$
\begin{aligned}
r_{p t}= & \left\{e\left[P_{f_{1}}-V_{f_{1}}\left(1+t_{i}\right)\right]+e\left[P_{f_{i}} \cdot s_{i}+V_{f_{i}} \cdot p_{r_{i}}\left(r_{i}-1\right)\right]\right. \\
& \left.+D_{t}-\sum_{j} a_{j_{l}} P_{d j}-a_{l i} W\right\} / a_{k i},
\end{aligned}
$$

and using (3) and (4) or (5) it follows that, the private rate of profit $\left(r_{p i}\right)$ and the implicit exchange rate $\left(e_{d i}\right.$ or $\left.e_{d t}^{\prime}\right)$ will be positively correlated. Thus, if the subsidy system succeeded in raising the relative implicit exchange rates for exports whose relative social profitability was highest, the net effect of the system on second-best welfare levels would have been positive. We can use the ICICI firm level data to test whether this was the case. In deriving the social profitability of the exports of the 10 ICICI firms, we made use of the Little-Mirrlees shadow prices that have been estimated for India within the Planning Commission, in $1974 .^{6}$ The resulting social rates of return to exporting in the 10 firms are given in column (3) of table 3, whilst columns $(4 \& 6)$ and (5) give the private rates of profit of the firms on their export sales and domestic sales respectively.

From this table it is apparent that the subsidy system has not in general succeeded in raising the implicit exchange rates for goods with higher social export profitability, and that the relative divergences between private and social profitability have been altered by the export incentive system in essentially arbitrary ways, for which no clear economic justification can be provided.

\subsection{Input subsidies}

Finally, there are various measures like duty drawbacks and freight subsidies, which attempt to offset the distortions between the social and market costs of particular inputs, to make the private costs of export production come closer to their social costs. To the extent that they thereby entail movement towards the equation of the social costs of production to the 'border' price of the exportable, they are socially desirable.

The extent to which these various input subsidies can bring the private and social costs of export production closer together is, however, limited by the continuing use of the 'indigenous availability' criterion in 1 mport licensing, and thus the virtual elimination of competitive imports. Nor has this problem been sought to be eased by the use of the exchange rate which could, in principle, lower the relative prices of (what the QR system has

"See Lal (forthcoming). 
converted into) virtually non-traded goods towards their relative international prices. The effective devaluation of the Rupee from the 1971 currency realignment till the recent (September 1975) linking to a basket of currencies (of about $17.8 \%$ on the export side and $19.6 \%$ on the import side $)^{7}$ must, however, have led to some increase in the relative competitiveness of these 'non-traded' goods, and hence to a closer approximation between their domestic and 'border' prices.

\section{Conclusions}

From the above evidence, apart from the duty drawbacks and freight subsidies, the other components of the Indian export incentive system (cash subsidies and REP licenses) do not seem to have necessarily had a favourable impact on attainable second-best welfare levels (when the extant import control system is accepted as a binding constraint). This is because the system does not correspond to the 'optimal' system which offsets the divergences between the private and social costs of production, and equates 'border' prices to the social costs of production (at Little-Mirrlees shadow prices) of exports.

\footnotetext{
${ }^{7}$ This has been derived by weightıng the depreciation of the Rupee between June 1971 and June 1975 vis-à-vis various currencies by the proportion of imports from and exports to these currency areas in 1975, from the data contained in Nayak (1977) and CSO (1976)
}

\section{References}

Bhagwati, J.N., 1968, The theory and practice of commercial policy-Departures from unified exchange rates, Special Papers in International Economics, no. 8 (Princeton University, Princeton, NJ).

Bhagwati, J.N. and P. Desai, 1970, India-Planning for industrialısation (Oxford).

Bhagwatı, J.N. and T.N. Srinivasan, 1976, Foreign trade regımes and economic development: India (N.B.E.R., Washington, DC).

Corden, W M , 1974, Trade policy and economic welfare (Oxford).

CSO, 1976, Basic statistics relatıng to the Indian economy, 1950-51 to 1971-75 (Department of Statıstıcs, Minıstry of Planning, New Delhı).

Dasgupta, P. and J.E. Stiglitz, 1974, Benefit-cost analysı and trade policies, Journal of Political Economy, Jan/Feb.

Dixit, A., 1975, Welfare effects of tax and price changes, Journal of Public Economics, Feb.

Hatta, T., 1977, A theory of piecemeal policy recommendations, Review of Economic Studies, Feb.

Lal, D., 1969, The implications of economic controls and of liberalization, ECAFE Growth Studies Series, no. 6 (United Nations, Bangkok).

Lal, D., 1972, A suggested balance of payments policy for less developed countries (with particular reference to India), Economia Internazionale, Aug

Lal, D., 1973, New economic polıcies for Indıa, Fabıan Research Series 311 (London).

Lal, D., 1974, Methods of project analysis-A review, World Bank Occasional Papers, no 16 (Johns Hopkins, Baltimore, MD).

Lal, D, forthcoming, Prices for planning (Heinemann Educational Books, London) 
Little, I.M.D. and J.A. Mirılees, 1974, Project appraisal and planning for developing countries (Heinemann, London).

Lloyd, P.J., 1974, A more general theory of price distortions in open economies, Journal of International Economics, Nov.

Nayak, S.S., 1977, Exchange rate policy under a regime of floating rates, Economic and Political Weekly, Jan.

Ramaswam, V.K., 1972, Trade and development, Ch. 6 (George Allen and Unwin, London). 


THE WORLD BANK

Headquarters:

1818 H Street, N.W.

Washington, D.C. 20433, U.S.A.

European Office

66, avenue d'léna

75116 Paris, France

Tokyo Office:

Kokusai Building,

1-1 Marunouchi 3-chome

Chiyoda-ku, Tokyo 100, Japan

The full range of World Bank publications, both free and for sale, is described in the World Bank Catalog of Publications, and of the continuing research program of the World Bank, in World Bank Research Program: Abstracts of Current Studies. The most recent edition of each is available without charge from:

\author{
PUBLICATIONS UNIT \\ THE WORLD BANK \\ 1818 H STREET, N.W \\ WASHINGTON, D.C. 20433 \\ U.S A.
}

